\title{
Teaching Model of Islamic Education
}

\section{Based on Direct Experience-Multidisciplinary in Brawijaya University Malang Indonesia}

\author{
Nur Chanifah \\ Brawijaya University \\ Malang, Indonesia \\ Email: nur.chanifah@ub.ac.id
}

\begin{abstract}
As a Compulsory subject taught in higher institution, the quality of teaching of Islamic education (PAI) has been greatly improved. Its existence serves as source of values in nurturing the students character and materializing the sense of religiousness in their entire life. The various problems of teaching PAI in higher institution are its limited credits, its independent learning pattern and students deviant behaviors. It demands the existence of PAI teaching model which can be used as a guidance to build students characters. This study aims to analyze and find teaching model of Islamic education for students characters building in Brawijaya University Malang. The data collection techniques are indepth interviews, participatory observation, and documentation. The results of the study show that the teaching model of Islamic education is integrated development, both in core learning activities and supporting learning. Its effect includes system, campus culture and student behavior including hard skill (learning achievement) and soft skill.
\end{abstract}

Keyword: Teaching model and character building

\section{INTRODUCTION}

In the context of higher institution, the regulation of islamic education has been regulated through the Higher Education Decree Number 43 of 2006. Based on the regulation, islamic education is one of the personality development courses (MPK) that must be followed by all students. Islamic education is intended to develop faith or devotion of students.

According to Muhaimin, the reality shows that there are several criticisms of the implementation of islamic education. The most criticisms about learning methodologies that are more focus for normative, theoretical, and cognitive aspect. Other aspects that are highlighted are the curriculum content and facilities that have not been able to generate enthusiasm and mutual awareness of student.

Not only criticism, but also many problems happened on islamic education in higher education. There are conceptual confusion of islamic education and minimal portion of credits for a very ideal goal of personality development. In addition, the orientation of the material and its evaluation are also still cognitivistic, have not touched the affection, and multidisciplinary of students' backgrounds. Therefore, islamic education needs to be redesigned so that can be more effective and efficient learning.

In this case, researchers used the learning model theory of Joyce and Weil. According to him, the learning model is a plan or pattern that can be used to form a curriculum. Learning models are arranged based on various principles or theories of knowledge. Joyce and Weil studied learning models based on learning theories that are classified into four, namely information processing learning models, social learning, personal learning, behavioral system learning.

\section{LITERATURE REVIEW}

\section{A. Islamic Education in higher institution}

Islamic Education in higher instution aims to provide a foundation to develop intellectuals student who believe and fear God Almighty, noble character, philosophical thinking, rational and dynamic attitude, broad-minded, participating in interfaith cooperation in framework for the development and utilization of technology and art for the national interest. While the main mission is to develop the student's personality so that become scientists who have faith and fear Allah, able to devote their knowledge to the welfare of mankind. Whereas the formulation of the national standard of islamic education in higher education was prepared based on the policy of the Directorate General of Higher Education, Ministry of National Education and Culture of the Republic of Indonesia, which was outlined in the decision of the Director General of Higher Education, Number 43 / DIKTI / Kep / 2006 concerning signs for implementing groups of personality development courses and the policy of the Directorate General of Islamic Education, Ministry of Religion of the Republic of 
Indonesia, which was stated in the National Standards book of islamic education at higher institution in 2010.

Based on the Decree Number 43 / DIKTI / Kep / 2006, the vision and mission of personality development courses is to emphasize the strengthening of student personality as a whole Indonesian human being, who is consistently able to realize basic religious and cultural values. The vision and mission are translated into the competence of the personality development courses which aims to master the ability to think, be rational and dynamic, have a broad view as an intellectual human being, as well as a description of the basic substance of the study of personality development courses.

The competency standard of personality development courses (includes Islamic education) which must be mastered by students includes knowledge of religious values, culture, and citizenship and is able to apply these values in daily life; have a strong personality; critical thinking: being rational, ethical, aesthetic, and dynamic; broad view; and democratic attitude. While the Basic Competencies expected from islamic education are to be scientists and professionals who are faithful and devoted to God Almighty, have noble character, and have a work ethic, and uphold human values and life.

On the other hand, Decree of the Minister of National Education Number 232 / U / 2000 and No.045 / U / 2002 shows the intended restructuring. In 2000 the contents of the islamic education curriculum in higher institution still continued the material that had been applied in the New Order period, even though this course had been included as one of the Personality Development Course. However, since 2002, the contents of the islamic education curriculum in higher institution have undergone a drastic change. In this curriculum, islamic education is one of personality development courses which uses a new approach known as the competency-based curriculum that highly prioritizes the competence of each subject in college.

Whereas in Article 5 paragraph (2) the Decree of the Director General of Higher Education of the Ministry of National Education No. 43 / Dikti / Kep / 2006, states that the learning held is an educational process, in which critical, analytical, inductive, deductive, and reflective discussions occur through participatory creative dialogue to achieve an understanding of the truth of the basic substance of the study, real work, and to foster lifelong learning motivation.

Meanwhile, based on Article 4 paragraph (1) of the Decree of the Director General of Higher Education of the Ministry of National Education number 43 / Dikti / Kep / 2006, islamic education covers 9 subjects, namely: God Almighty and Godhead (faith and devotion and divine philosophy / theology); humans (Human nature, human dignity, and human responsibility); law (fostering awareness to obey God's law and the prophetic function of religion in law); moral (religion as a source of moral and noble character in life); science, technology, and art / science (science, science and charity as a unity; the obligation to demand and practice knowledge; and the responsibility of scientists and artists); harmony between religious believers (religion is God's grace for all and togetherness in religious plurality); the community (civilized and prosperous society; the role of religious community in creating a civilized and prosperous society; as well as human rights / human rights and democracy); culture (academic culture and work ethic, openness and fairness); and politics (religious contributions in political life and the role of religion in realizing national unity).

\section{B. Teaching Model of Islamic Education}

According to Joyce \& Weil, The teaching model is a visualization or conceptual framework that used as a guide in carrying out learning activities. For this reason, it is necessary to give attention to the characteristics of the learning model, namely:

1. Based on educational theory and learning theory from experts.

2. Having a specific mission or goal. Can be used as guidelines for improving learning activities in the classroom.

3. Having parts of the model called: the sequence of learning steps (syntax), the existence of the principles of reaction, the social system, and the support system.

4. Having an impact as a result of the applied learning model. These impacts include: the impact of learning, namely learning outcomes that can be measured, the effects of accompaniment, namely long-term learning outcomes.

5. Make teaching preparation (instructional design) with the chosen learning model guidelines.

The learning model can be classified into several groups. Joyce and Weil classified into four major groups, namely:

a. Learning to process information. This model emphasizes ways to enhance the natural drive to form meaning about the world by acquiring and processing data, feeling problems and producing the right solutions, and developing concepts and languages to transfer these solutions or data. This model is based on cognitive learning theory (Piaget) and is oriented towards the ability of students to process information that can improve their abilities. Information processing theory was pioneered by Robert Gagne (1985). The assumption is that learning is a very important factor in development. The development is the cumulative result of learning. Learning strategies included in this group are inductive thinking, concept discovery, word-inductive inductive models, 
scientific research, research exercises, mnemonics (memory assistance), synectics, and advance organizer.

b. Learning social interaction that includes positive learning-interdependence partners, structured research, group investigation, role playing, and jurisprudence research. This model is based on learning Gestalt. Gestalt learning theory was pioneered by Max Wertheimer along with Kurt Koffka and Kohler, conducting experiments on visual observation with physical phenomena. The point of view of Gestalt is that certain objects or events will be seen as an organized whole. The meaning of an object or event lies in the whole form (gestalt) and not its parts.

c. Personal learning groups. This model starts from the Humanistic theory, which is oriented towards individual self-development. His main concern is emotional students to develop productive relationships with their environment. Individuals are assisted through efforts to create a stimulating environment so that the individual feels comfortable to carry out his duties and develops his abilities and connects them to other productive things. Humanistic figures are Abraham Maslow, R. Rogers, C. Buhler, and Arthur Comb. Learning strategies included in this group include teaching without direction and increasing self-esteem.

d. Behavioral system learning groups. This model is based on behavioristic learning theory, which aims to develop an efficient system to sort learning tasks and shape behavior by manipulating reinforcement. The principle in this model is that humans are selfimprovement communication systems that can change their behavior when responding to information. Learning models included in this group are mastery learning, direct instruction, simulation, social learning, and strengthening task performance.

Before determining the learning model that will be used in learning activities, there are several things that must be considered in choosing it:

1) Consideration of the objectives to be achieved.

2) Consideration relating to learning materials or materials.

3) Consideration from the angle of students or students.

4) Other non-technical considerations.

\section{RESEARCH METHODS}

This research is categorized in naturalistic research with interpretive paradigm and its type is Case Study. The location of this study is Brawijaya University and the unit of analysis is the Center for personality development course (MPK) and center of religious development (PPA). Data and its sources include words and actions, then written data sources, photos, and statistical data. Data collection techniques include participant observation, in-depth interviews and documentation. Technique Analysis of the data using descriptive technique through interactive analysis model from Miles and Hubermen. In the interactive analysis model, data collection, condensation data, data presentation and conclusion are interactive (continuous, repetitive, and continuous) cycles and abstracting them into formal findings. While the techniques of checking the validity of data include: (1) credibility by using triangulation technique in methods and sources, and member check which is done by confirming data to informants or other members. (2) Transferability by thick description (detailed description). (3) depend ability by involving dependent auditor as expert consultant that is the promoter and examiner. (4) confirm ability is criteria for determining quality of research results or not. Confirmability is required to know whether the data obtained objectively or not. All of the results of data collection, conclusion, substantive findings and formal findings have been confirmed to the owner of data or informant of research.

\section{FINDING AND DISCUSSION OF RESEARCH}

The learning model of Islamic education found in Brawijaya University is a "integrated development". The development follows the central-decentralized instruction model with the first learning phase is direct instruction, the second phase is contextual teaching and learning, the third and fourth phases are experiential learning and meaningful learning.

The learning model is not only based on experience, but also students multidisciplinary background. Student discipline is important so that there is no dichotomy between religious education and general education. This is like Miskawaih's idea about multidisciplinary learning. Ibn Miskawaih also does not discriminate between religious sciences and non-religious sciences.

The background of the discipline is also a reference in the development of teaching materials or student handbooks. To further deepen Islam and the disciplines pursued by students. In Brawijaya University, it is carried out through both core and supporting learning. Core learning are activities following curriculum from ministry of research and higher education, for example method of direct observation. Meanwhile supporting learning are activities supporting the core learning designed by lecturer, for example tutorial activities held once a semester, community service, and self-assessment. In addition, there is the involvement of mosques and other institutions related to the material being taught. 
For more details how the learning model findings can be seen in the picture below:

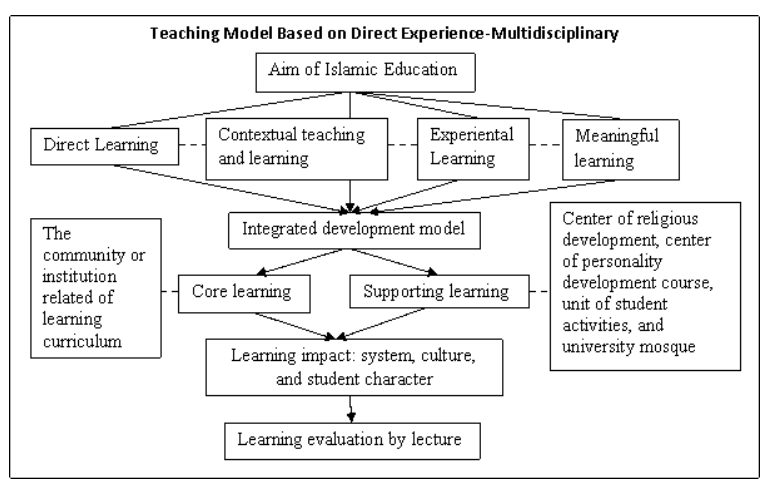

Fig 1: Teaching model based on direct experience multidisciplinary

Thus, it can be concluded that teaching model based on experience-multidisciplinary is based on the theory of direct learning, contextual learning, experiential learning, and meaningful learning. To realize it, the lecture must make cooperation with other institution or center in Brawijaya university, for example center of religious development, Raden patah mosque, and center of personality development courses. In addition, the corporation can be realized with student activity units, for example Pramuka, religious development units, and student executive board. The effects of teaching model are included on system, campus culture, and character.

\section{ACKNOWLEDGMENT}

The learning model of Islamic education based on direct experience in brawijaya university is an integrated development model, considering that Islamic education is only given 2 credits in one semester. The development is not only on core learning activities, but also supporting learning. The development follows the central-decentralized instruction model with the first learning phase: direct instruction, the second phase of contextual teaching and learning, and the third phase of experiential learning and meaningful learning. The effects are system, campus culture, and student character.

\section{REFERENCES}

[1] Daradjat, Zakiah, dkk, Dasar-dasar Agama Islam, Jakarta: Bulan Bintang, 1984

[2] Hamka, Rekonstruksi kurikulum Pendidikan Agama Islam di Perguruan Tinggi Umum pascapemerintahan orde baru, Jurnal Hunafa, Vol. 6 , No.1, April 2009

[3] Hidayatullah, Furqon, Pendidikan Karakter, Membangun Peradaban Bangsa, Surakarta: Yuma Pustaka, 2010

[4] Home, Henry, Lord Kames, Essays on the Principles of Morality and Natural Religion, USA, Liberty Fund, 2005
[5] Joyce, Bruce, Marsha Weil, dan Emily Calhoun, Models of Teaching, terj. Ahmad Fawaid dan Ateilla Mirza, Yogayakarta: Pustaka Pelajar, 2011

[6] Khoir HS, Abdul. Kurikulum Mata Kuliah Pengembangan Kepribadian Pendidikan Agama Islam Universitas Islam “45” Bekasi, Jurnal Turats, Vol. 7, No. 2, Agustus 2011

[7] Moleong, Lexy J. Moleong. Metedologi Penelitian Kualitatif, Bandung: Remaja Rosdakarya, 2005

[8] Muhaimin, Nuansa Baru Pendidikan Islam, Mengurai Benang Kusut Dunia Pendidikan, RajaGrafindo Persada, Jakarta, 2006

[9] Muhaimin, Pengembangan Kurikulum Pendidikan Agama Islam di Sekolah, Madrasah, dan Perguruan Tinggi, Jakarta: Raja Grafindopersada, 2005

10] Munip, Abdul, Perkuliahan Pendidikan Agama Islam di Perguruan Tinggi Negeri Sebuah catatan Lapangan), Jurnal Pendidikan Agama Islam Vol. V, No. 1,2008

[11]Nashir, Haedar, Pendidikan Karakter berbasis Agama dan Budaya, Yogyakarta: Multi Presindo, 2013

[12]Saidah, Nur, Pendidikan Agama Islam, Problem dan Tantangannya sebagai komponen matakuliah pengembangan kepribadian (MPK), Jurnal Pendidikan Agama Islam Vol. N, No. 1, 2007

[13]Robert K. Yin. 2009. Case Study Research: Design and Methods, United Kingdom, SAGE

[14]Rusman, Model-model pembelajaran mengembangkan profesionalisme Guru, Jakarta: Rajawali Press, 2010

[15]Samani, Muchlas dan Hariyanto, Konsep dan Model Pendidikan Karakter, Bandung: Remaja Rosdakarya, 2013

[16]Tobroni, Relasi Kemanusiaan dalam Keberagamaan, Mengembangkan Etika Sosial Melalui Pendidikan), Bandung: Karya Putra Darwati, 2012

[17]Tobroni, Spiritual Leadership: A Solution of The Leadership crisis in Islamic education in Indonesia, British Journal of Education, Vol.3, No.11, November 2015 